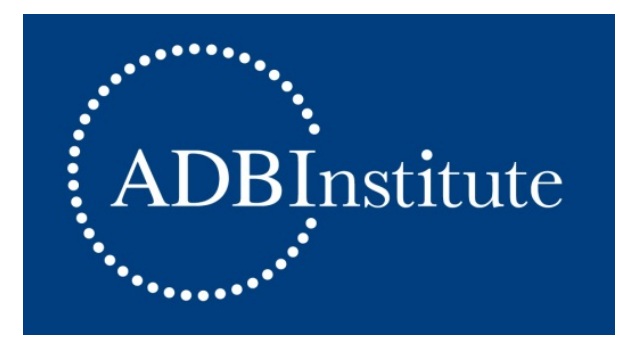

ADBI Working Paper Series

\title{
A MICROECONOMIC ANALYSIS OF THE DECLINING LABOR SHARE IN JAPAN
}

Kyoji Fukao, Koji Ito,

and Cristiano Perugini

No. 925

February 2019

\section{Asian Development Bank Institute}


Kyoji Fukao is a professor of economics at the Institute of Economic Research of Hitotsubashi University in Japan. Koji Ito is a consulting fellow at the Ministry of Economy, Trade, and Industry in Japan. Cristiano Perugini is an associate professor at the University of Perugia in Italy.

The views expressed in this paper are the views of the author and do not necessarily reflect the views or policies of $A D B I, A D B$, its Board of Directors, or the governments they represent. $\mathrm{ADBI}$ does not guarantee the accuracy of the data included in this paper and accepts no responsibility for any consequences of their use. Terminology used may not necessarily be consistent with ADB official terms.

Working papers are subject to formal revision and correction before they are finalized and considered published.

The Working Paper series is a continuation of the formerly named Discussion Paper series; the numbering of the papers continued without interruption or change. ADBl's working papers reflect initial ideas on a topic and are posted online for discussion. Some working papers may develop into other forms of publication.

\section{Suggested citation:}

Fukao, K., K. Ito, and C. Perugini. 2019. A Microeconomic Analysis of the Declining Labor Share in Japan. ADBI Working Paper 925. Tokyo: Asian Development Bank Institute. Available: https://www.adb.org/publications/microeconomic-analysis-declining-labor-sharejapan

Please contact the authors for information about this paper.

Email: ito-koji@meti.go.jp

Asian Development Bank Institute Kasumigaseki Building, 8th Floor 3-2-5 Kasumigaseki, Chiyoda-ku Tokyo 100-6008, Japan

Tel: $\quad+81-3-3593-5500$

Fax: $\quad+81-3-3593-5571$

URL: $\quad$ www.adbi.org

E-mail: info@adbi.org

(C) 2019 Asian Development Bank Institute 


\begin{abstract}
The labor share in Japan has been declining significantly over the last three decades, accompanied by persistent stagnation and an unprecedented increase in economic inequalities. Since these dynamics are likely to be interrelated, understanding the drivers of the labor share might contribute significantly to the Japanese economic and policy debate. Surprisingly, the existing literature on the labor share in Japan is rather limited and confined to country or industry studies. We first attempt to analyze the drivers of the labor share in Japan at the firm level. To this aim, we employ a panel of manufacturing firms from the Basic Survey of Japanese Business Structure and Activities, spanning from 2001 to 2012. By means of panel data estimators, we show how, besides technological variables, firms' labor share depends significantly on the share of regular workers, on the importance of firms' international engagement, and on various institutional settings of the product and labor markets.
\end{abstract}

Keywords: labor share, firm-level analysis, Japan, panel data

JEL Classification: D33, F61, J30, L11 


\section{Contents}

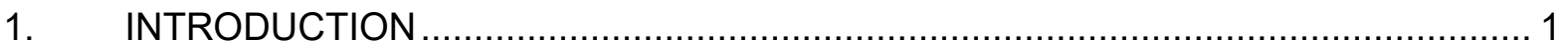

2. THE DRIVERS OF THE LABOR SHARE: LITERATURE BACKGROUND ............... 2

3. EMPIRICAL MODEL AND ESTIMATION STRATEGY ….................................... 5

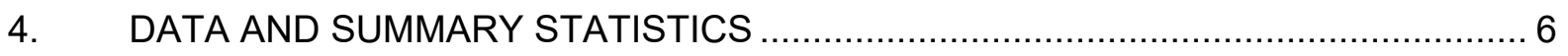

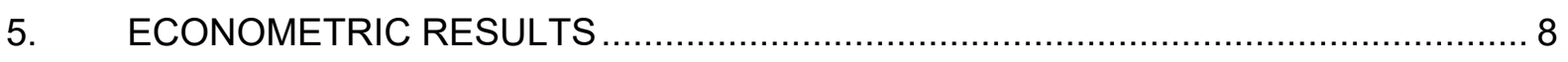

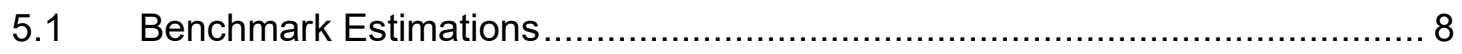

$5.2 \quad$ Estimation with Sector-Level Variables ............................................... 11

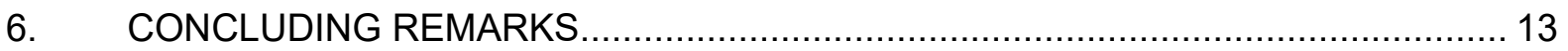

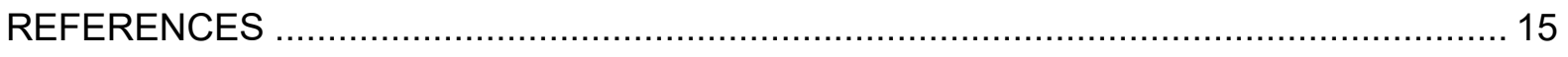

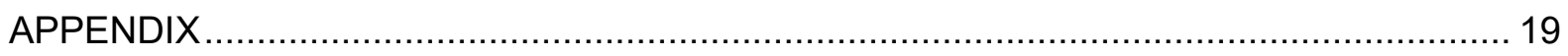




\section{INTRODUCTION}

The empirical evidence of the latest decades has challenged what researchers previously regarded as one of the stylized facts of modern economic growth, that is, the constancy of factors' shares of income (Kaldor 1961). The decline in the labor share (LS), which started during the 1970s in most developed countries, has stimulated extensive research efforts to provide possible explanations and adequate policy responses. Research has identified the drivers of such dynamics as factors related to the production function (technological change and inputs' elasticity of substitution), the consequences of increased globalization of markets for firms' structure and organization, and institutional factors affecting the relative bargaining power of capital and labor. Despite the purely microeconomic nature of the potential drivers of the labor share, empirical research has so far focused mainly on the aggregate (country or sector) level. A few notable exceptions exist. Berkovitz, Ma, and Nishioka (2017) studied the evolution of the labor share over the period 1998-2007 for a sample of Chinese firms, associating the decline primarily with institutional factors, namely market reforms in the state sector and product market deregulation; in addition, the increasing importance of large "superstar" firms, with relevant market power and a small labor share, is an important explanation for the decline. In an earlier paper, the same authors (Berkovitz, Ma, and Nishioka 2015) distinguished the drivers of the decline in the labor share in the manufacturing sector into the increasing market power and capital intensity of Chinese firms and the decreasing political pressure on state-owned firms. Hwang and Lee (2015) explored the drivers of the labor share of firms in the Republic of Korea during the period 2005-2011 and found that, besides the factors related to production technology and market power, employees' bargaining power and the corporate labor strategy are pivotal in explaining the heterogeneity in the labor share. Within the European context, Sieghenthaler and Stucki (2015) examined a sample of Swiss firms between 2001 and 2010 and identified the share of workers using ICT as the main factor behind the declining labor share. Kyyra and Maliranta (2008), using Finnish plant-level data (from 1974 to 2001), found that the labor share was virtually constant within firms, while its aggregate decline was related to a compositional shift from high- to low-labor-share plants. Bockerman and Maliranta (2012) obtained similar outcomes for Finland by aggregating establishment-level data to the industry level. Growiec (2012), analyzing a sample of Polish firms for the period 1995-2008, concluded that sector-specific factors, such as changes in the ownership structure and human capital accumulation, explain a large fraction of the observed downward trend in the labor share. Dall'Aglio, Magnani, and Marchini (2015) analyzed the medium- and short-run dynamics of the labor share in Italian firms from 2004 to 2007. They found that the capital-output ratio plays a key role in both the short and the medium run; in addition, an increase in the markup over production costs and the implementation of technical progress have positive effects on the labor share in the short run and negative effects in the medium run. Lastly, more exposure to international competition reduces the labor share in the short run, probably favoring the bargaining power of entrepreneurs relative to employees and leading to wage moderation. Lastly, Perugini, Vecchi, and Venturini (2017), using a sample of firms from 6 EU countries, showed that the labor share decreases for firms engaged in internationalization processes, but this effect is not related to differences in the composition of the labor force, technological factors, and firms' market power. 
Our paper contributes to this literature relying on data for Japanese manufacturing firms for the period 2001-2012. This is the first microeconomic-level analysis for this country, for which empirical evidence on the labor share movements is quite limited (see Takeuchi 2005; Wakita 2006; Agnese and Sala 2011; Fukao and Perugini 2018). While studying the microeconomic drivers of the labor share, we focus on a comprehensive set of aspects related to technology, factors' intensity, internationalization patterns, and the composition of the workforce. We also exploit the sectoral detail of our data to allow for industry-specific employment features and product and labor market institutional settings.

We organize the paper as follows. In the next section (2), we provide a bird's eye view of the relevant literature on the drivers of the labor share. Section 3 describes the empirical modeling approach and methods. In section 4, we illustrate the dataset and provide some preliminary descriptive evidence, while, in Section 5, we present the results of our estimations. Section 6 summarizes and concludes.

\section{THE DRIVERS OF THE LABOR SHARE: LITERATURE BACKGROUND}

The literature provides various explanations for the decline in the labor share that, despite often being conceptually separated, are in fact closely related to each other. Factors' productivity and, in the presence of market frictions, their relative bargaining power ultimately determine the distribution of income that the production process generates. This implies that all possible drivers of the income share accruing to workers (or, complementarily, to capital and profits) are mutually related. Technological change, for example, has been increasingly capital augmenting, and this has resulted in more capital-intensive production processes; this could explain, along with greater substitutability of labor with capital, the decrease in the labor share (Bentolila and Saint-Paul 2003; Lawless and Whelan 2011). The macroeconomic evidence emphasizes that capital deepening is the main factor driving the decline in the labor share, provided that the elasticity of substitution between capital and labor is larger than one (Karabarbounis and Neiman 2014; Piketty 2014; Piketty and Zucman 2014). It is possible to extend this baseline conceptual structure in various directions. First, not all studies have agreed on the level of the elasticity of substitution, with some of them arguing that capital and labor are gross complements instead of substitutes (Antràs 2004). More importantly, the framework gains much in explanatory power when taking labor heterogeneity into account. It is indeed possible to include high- and low-skilled workers separately in the production function (a general CES type to guarantee flexibility in the elasticity of substitution) and for their elasticity of substitution to differ (Arpaia, Prez, and Pichelmann 2009; Elsby, Hobijn, and Sahin 2013). In this way, it is possible to model and empirically estimate the consequences of skill-biased technological change in terms of both skilled/unskilled relative demand and prices. Many studies have found that technological change, which the introduction of innovation and communication technologies (ICTs) induces, explains a remarkable proportion of the aggregate or sector-level labor share decline (e.g., European Commission 2007; Lawless and Whelan 2011). However, as much as ICT is likely to replace low- and medium-skilled labor, it might also be complementary to high-skilled labor (Acemoglu and Autor 2011). Hence, the overall effect of skill-biased technological change on the labor share depends on the interplay between different types of labor complementarity/substitutability levels and their relative skill premia. Karabarbounis and Neiman (2014) documented that the change in the relative prices of ICT compared with other assets, along with possible complementarities between ICT and high-skilled labor, 
explains a large fraction of the variation in the labor share. Also related to the ICT/skills debate is the potential impact of organizational change, which tends to be biased toward high-skilled labor (Caroli and Van Reenen 2001; Piva, Santarelli, and Vivarelli 2005).

More recently, research has devoted attention to another side of capital heterogeneity, distinguishing the impact on the LS of tangible and intangible capital assets. Koh, Santaeulàlia-Llopis, and Zheng (2016) found that the declining trend of the labor share in the US is entirely due to the increase in the capital intensity of intellectual property products (IPPs); O'Mahony, Vecchi, and Venturini (2018) showed more mixed results, with some types of intangible capital (those complementary to ICT and innovative capital) increasing the labor share and others (economic competencies) decreasing it.

Relaxing the assumption of perfectly competitive (product and input) markets opens the way to additional potential drivers of the labor share. If remuneration does not exactly mirror workers' marginal productivity, the extent to which emerging rents accrue to capital or labor becomes crucial to explaining the dynamics in the factor share of income (Blanchard and Giavazzi 2003). The economic and institutional factors shaping the bargaining power of workers vis-à-vis employers largely drive rent sharing. A firm's market power (measured by its markup) indeed determines the size of the rent. If price markups are larger than wage markups, researchers expect a lower degree of competition to decrease the labor share (Azmat, Manning, and Van Reenen 2012). Barkai (2016) and Autor et al. (2017) provided evidence of a negative correlation between the market concentration and the labor share in the US. The extent of this phenomenon depends on workers' bargaining power, which in turn stems from the general macroeconomic conditions and institutional settings (European Commission 2007; Bental and Demougin 2010). In fact, the decline in labor collective organizations (union density, collective bargaining systems) and labor market regulation (employment protection, minimum wage provisions) that has characterized virtually all OECD countries in the last decades may have contributed to the decreasing trend in the labor share (see Bentolila and Saint-Paul 2003; OECD 2011).

The forces related to globalization add complexity to all the sources of labor share changes. According to the Heckscher-Ohlin (HO) model, researchers expect trade to drive specialization in production sectors that reflect countries' comparative advantage, resulting from relative factor endowments. Therefore, developed countries specialize in capital-intensive industries, and this drives the labor share downward, provided that the elasticity of substitution is lower than one (i.e., capital and labor are gross complements) (European Commission 2007). Modern versions of the $\mathrm{HO}$ model distinguish between high-skilled and low-skilled labor, with the first normally being a substitute for and the second a complement to capital (Wood 1994). This complicates the predictions of the model in terms of labor share developments, since the overall effect now depends on the relative elasticity of substitution of the different types of labor with respect to capital. However, at least we can predict that international trade (including intra-industry trade) will reduce labor share as well as skill premium through its factor price equalization mechanism. The empirical evidence tends to support the predictions of the HO framework (see, for example, Guscina 2006; European Commission 2007; ILO 2011). Decreuse and Maarek (2011), drawing on Davis (1998), showed that, in countries characterized by wage rigidity, trade induces factor reallocation toward capital-intensive and low-labor-share sectors. Globalization therefore increases the aggregate elasticity of substitution between capital and labor or equivalently reduces the aggregate elasticity of the labor demand with respect to the relative factor cost. On the contrary, in free-wage countries, globalization does not alter factor allocation across sectors, and the proportion of industry value added in the GDP does not change. As a result, the aggregate labor share stays constant. 
Even more relevant to our analysis of Japan is the fact that intra-industry trade between developed countries has become prevalent. This has been the result of a shift toward the production of horizontally differentiated goods, which normally leads firms to benefit from some market power and to gain an increase in their markups and profits. "New" new trade theories emphasize the importance of firm heterogeneity (in terms of productivity) as a key driver of the probability of entering, surviving, and producing profits in international markets in the presence of fixed general and trade linked costs, which originate economies of scale (Melitz 2003). Competitive pressure due to exposure to international trade is an important stimulus for productivity-enhancing microrestructuring (creative destruction) within industries (e.g., Bernard et al. 2007; Lileeva 2008; Bockerman and Maliranta 2012). Knowing what drives productivity upward is therefore crucial in understanding the distributive outcomes of internationalization: if higher productivity is driven by higher capital intensity aimed at reducing labor costs, international firms will tend to have a smaller labor share. However, once again, if capital and skilled labor are complements, the final effect on the labor share will depend on the relative change in the workforce composition by skills within the firm.

Additionally, in imperfectly competitive labor markets, globalization forces tend to affect adversely the bargaining position of labor, a relatively less mobile factor of production compared to capital. Reduced barriers to trade accentuate the asymmetries between groups that can cross international borders (owners of capital and a few highly skilled workers) and those that cannot (the great majority of workers) (Rodrik 1997; Slaughter 2000). The fixed costs of relocating are indeed much larger for workers (especially unskilled ones) than for capital. Their bargaining position will consequently deteriorate due to an increase in the outside options of firms (IMF 2007). The threat of relocating the production process (or part of it) through FDI, outsourcing segments of the productive chain abroad or importing intermediate inputs, is therefore likely to compress wages and lead to a decline in the labor share. In addition, when domestic firms in developed, high-wage countries decide to produce abroad or to offshore the most unskilled-labor-intensive segments to respond to labor cost pressures, the labor demand for low-skilled workers decreases (see, for example, Crinò 2012) and the wage elasticity grows. In fact, unskilled workers are more easily replaceable with the services of other people across national boundaries. Both factors drive the labor share downward, as various empirical studies on developed countries have shown (Harrison 2002; Guscina 2006; Jaumotte and Tytell 2007; Jayadev 2007). Hutchinson and Persyn (2012) also provided a theoretical framework in which foreign competition limits the scope for the union wage demand. Obviously, researchers expect the opposite (or no effects of internationalization/offshoring) in low-wage countries, in which workers would probably benefit from the division of labor across countries (Bassanini and Manfredi 2012). Guerriero and Sen (2012) provided empirical evidence concerning the opposite effect of trade openness on the labor share for OECD (negative) and non-OECD (positive) countries; when they distinguished between developed and developed countries, they found that the effect of openness is in both cases positive but much weaker for the advanced economies.

If heterogeneous labor is introduced into the models, the overall impact becomes unclear, because skilled workers could gain from outsourcing (Feenstra and Hanson 1999) and the overall change in the labor share depends on the relative size of the gains/losses of the two groups. 


\section{EMPIRICAL MODEL AND ESTIMATION STRATEGY}

Our empirical model is based on the framework that Bentolila and Saint Paul (2003) proposed; they showed that, in the presence of two factors of production ( $K$ and $L$ ), and under the assumptions of constant returns to scale, capital- and labor-augmenting technical progress, and competitive markets, a unique function $g$ exists that explains the labor share in firm $i\left(L S^{i}\right)$, based on the capital-output ratio $\left(K_{i},=k_{i} / y_{i}\right)$ and on changes in the capital-augmenting technological progress $\left(A_{i} K_{i}\right)$. This relationship-the so-called SK relationship $\left[L S^{i}=g\left(A_{i} K_{i}\right)\right.$ ]-is stable as long as the marginal product of labor is equal to the real wage. The nature of our data (see section 4) allows us to distinguish different types of non-labor inputs that might have different levels of substitutability with labor: tangible capital $\left(k_{T}\right)$, intangible assets (expenditures on R\&D and advertisement- $e_{I N T}$ ), and ICT assets (expenditure on $e_{I C T}$ ). As Fukao and Perugini (2018) showed, under certain assumptions, it is possible to extend the Bentolila-Saint Paul model to more than two inputs (labor and capital) by assuming that the production activity of each firm consists of different processes (in our case, a tangible capital-intensive process, an intangible asset-intensive process, and an ICT asset-intensive process), all with constant elasticities of substitution between non-labor input and labor and with unitary elasticity of substitution between them. Under such circumstances, it is possible to express the labor share as a function of tangible capital intensity (on output), intangible capital intensity, and ICT asset intensity, with changes in technological progress shifting this extended SK schedule. Any factor able to create a gap between the marginal product of labor and the real wage (as those explained in section 2) moves the economy off the SK schedule.

Following Bentolila and Saint-Paul (2003), we assume a multiplicative form of the extended labor share function:

$$
L S^{i j t}=g\left(K_{T}^{i j t}, E_{I N T}^{i j t}, E_{I C T}^{i j t}, C^{i j t}\right) h\left(Z^{i j t}\right)
$$

where superscripts $i, j$, and $t$ denote firms, sectors, and years, respectively, and the function $g($.) describes the labor share determinants strictly derived from the production function (the SK schedule). $K_{T}^{i j t}$ corresponds to $\frac{k_{T}^{i j t}}{y^{i j t}} ; E_{I N T}^{i j t}$ corresponds to $\frac{e_{I N T}^{i j t} \text {; }}{y^{i j t}}$; and $E_{I C T}^{i j t}$ corresponds to $\frac{e_{I I T}^{i j t}}{y^{i j t}}$. Due to the data availability, we use intangible and ICT assets to approximate the relevant annual amount of real expenditures of firms. $C^{i j t}$ is a measure of technological change that summarizes the effects of all types of technical change that are not labor augmenting $\left(A_{T}, A_{I N T}, A_{I C T}\right)$. The separate exponential function $h($.$) is instead meant to account for the other potential factors \left(Z^{i t}\right)$ that shift the economy off the SK schedule. They include internationalization patterns, employment characteristics, and product and labor market institutional factors that are able to shape the relative bargaining power of labor and capital.

Assuming that both $g($.$) and h($.$) are also multiplicative and by taking logs, we can$ express the labor share as:

$$
\begin{aligned}
\ln L S^{i j t} & =\gamma \ln L S^{i j t-1}+\beta_{0} \ln \left(C^{i j t}\right)+\beta_{1} \ln \left(K^{i j t}{ }_{T}\right)+\beta_{2} \ln \left(E^{i j t}{ }_{I N T}\right)+\beta_{3} \ln \left(E^{i j t}{ }_{I C T}\right)+\gamma \ln \left(Z^{i j t}\right) \\
& +\alpha^{i}+\lambda^{j t}+\varepsilon^{i j t}
\end{aligned}
$$


where $\alpha^{i}$ are firm fixed effects, $\lambda^{j t}$ is a set of industry/year dummies, and $\varepsilon^{i j t}$ is a residual error term.

Modeling the drivers of the labor share poses some identification issues. A relevant one relates to omitted variable bias, which, despite the advantages that firm-specific intercepts guarantee in our case, might persist due to the fact that the labor share might be characterized by high within-firm inertia and therefore be time persistent. The inclusion of the lagged dependent variable among the regressors in equation [2] is the standard approach to address this issue. However, the presence among the right-hand side variables of the lagged $\ln L S^{i j t-1}$, which is correlated with the composite error $\left(\alpha^{i}+\varepsilon^{i j t}\right)$, leads to inconsistent parameter estimates when we account for firms' heterogeneity by means of conventional fixed- or random-effect estimators (Baltagi Badi 2001). To address this issue, we opt for the GMM estimator that Arellano and Bond (1991) proposed, which they specifically designed for situations with panels of a relatively short time dimension and many individual units, fixed individual effects implying unobserved heterogeneity, and right-hand variables that are not strictly endogenous (i.e., correlated with the past and possibly the current realization of the error).

\section{DATA AND SUMMARY STATISTICS}

We use firm-level panel data from the "Basic Survey of Japanese Business Structure and Activities" (hereinafter "the survey"), conducted annually by the Ministry of Economy, Trade and Industry (METI). The survey covers all firms with at least 50 employees or 30 million yen of paid-in capital in the Japanese manufacturing, mining, and most of the service sectors. We limit our sample here to manufacturing and to the period 2001-2012, since many important variables, such as exports and imports, are not available for previous years. The questionnaire of the survey covers firms' broad activities and characteristics, such as sales, number of employees, tangible assets and intangible investment, and international activities (see Table A1 in the Appendix for the full list of variables that we use). Unfortunately, the information on workforce characteristics is quite limited, and the survey does not cover some crucial aspects (such as its composition by gender, age, education/skills, and wage levels). As a second-best choice, we exploit the detailed industry breakdown of the survey (41 subsectors of manufacturing) and use industry-level data on workforce characteristics, which we construct using the Japan Industrial Productivity (JIP) database.

Table 1 outlines some descriptive statistics of the variables used in our analysis. The size of the unbalanced panel of firms (pooled, all years) is 147,725 . The average labor share (LS-labor cost over value added) during the period is $66.3 \%$, and, consistent with the existing empirical evidence (see Fukao and Perugini 2018), it shows a clear declining trend over the period considered (Figure 1). In particular, while the labor share fluctuated around $70 \%$ at the beginning of the 2000 s, it declined in the following years to about 64\%. A new declining trend in 2011 and 2012 followed the countercyclical increase observable in 2009 and 2010. 
Table 1: Summary Statistics

\begin{tabular}{lccccc}
\hline \multicolumn{1}{c}{ Variables } & Observations & Mean & Std & Min. & Max. \\
\hline LS & 147,725 & 0.663 & 0.165 & 0 & 1 \\
TFP & 147,067 & 1.002 & 0.378 & 0.392 & 95.930 \\
KT & 147,725 & 0.258 & 0.341 & 0 & 60.283 \\
E INT & 147,725 & 0.013 & 0.029 & 0 & 2.324 \\
E ICT & 147,565 & 0.005 & 0.038 & 0 & 7.825 \\
PAT (d) & 147,725 & 0.307 & 0.461 & 0 & 1 \\
REG & 147,601 & 0.877 & 0.173 & 0 & 1 \\
EXP (d) & 147,725 & 0.318 & 0.466 & 0 & 1 \\
IMP (d) & 147,725 & 0.289 & 0.453 & 0 & 1 \\
FDI (d) & 147,725 & 0.072 & 0.259 & 0 & 1 \\
FOREIGN (d) & 147,725 & 0.092 & 0.289 & 0 & 1 \\
EXP_S & 147,725 & 0.044 & 0.122 & 0 & 1 \\
IMP_S & 147,565 & 0.031 & 0.099 & 0 & 2.963 \\
FOREIGN_s & 147,725 & 0.002 & 0.016 & 0 & 1 \\
SIZE & 147,725 & 396.766 & $1,607.890$ & 50 & 80,840 \\
SME (d) & 147,725 & 0.766 & 0.423 & 0 & 1 \\
PARENT (d) & 147,725 & 0.337 & 0.473 & 0 & 1 \\
FIRMAGE & 147,086 & 43.254 & 18.697 & 0 & 657 \\
\hline
\end{tabular}

Source: Own elaborations on the Basic Survey of Japanese Business Structure and Activities.

Figure 1: Average Labor Share of Japanese Manufacturing Firms, by Year

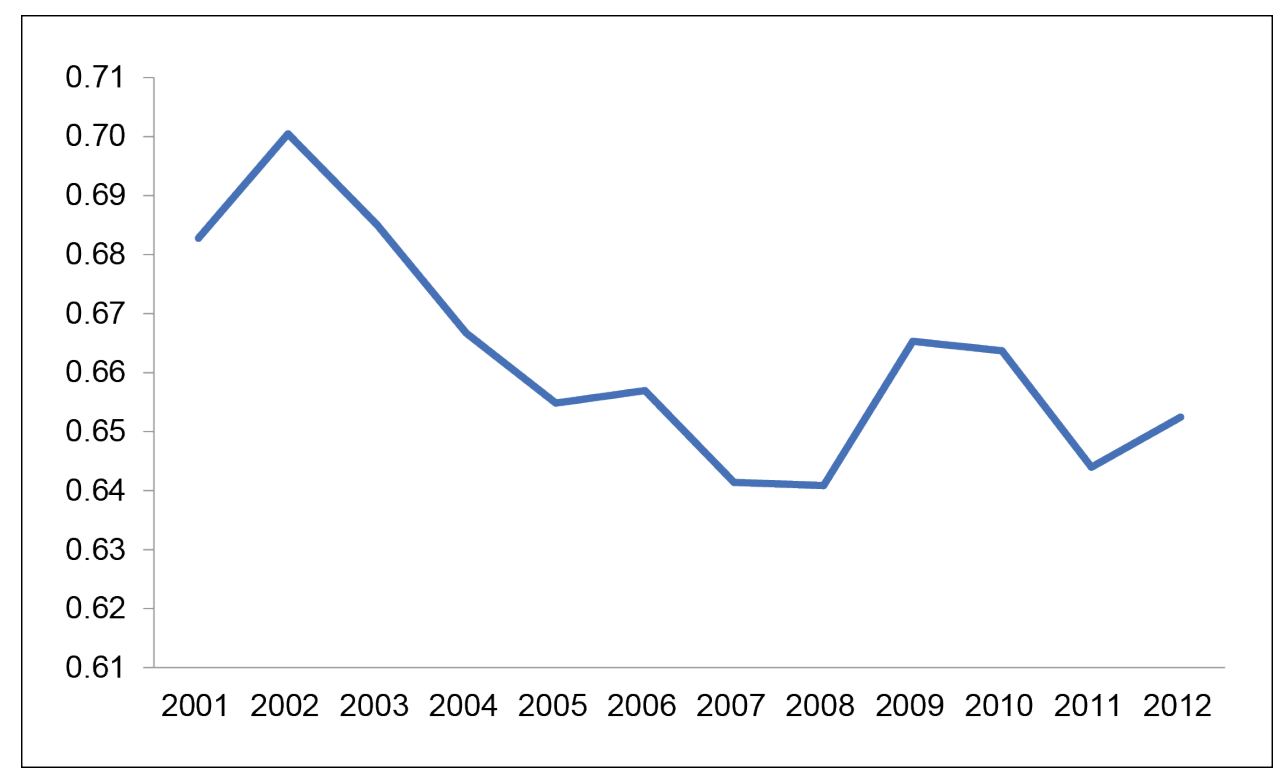

Source: Own elaborations on the Basic Survey of Japanese Business Structure and Activities.

The set of technology-related indicators shows that R\&D-intensive firms do not have a dominant share. The R\&D expenditure to sales ratio is $0.9 \%$, growing to $1.3 \%$ if we add expenses of other intangible assets (advertisement) (variable $e_{I N T}$ ). Approximately one-third of firms develop their own patents, while the share of regular employees in total employees is close to $90 \%$. 
The variables related to internationalization indicate that firms engaged in international business are limited in number. The share of exporting and importing firms is about $32 \%$ and $29 \%$, respectively. Firms with foreign direct investments (FDI) are even fewer $(7 \%)$, while firms partially or completely owned by foreign companies amount to $9 \%$ of the total. Regarding firm size, the average number of employees is close to 400 , but the proportion of small and medium enterprises (companies with 300 or fewer employees) amounts to $76.6 \%$. About $34 \%$ of firms are subsidiaries of other companies.

\section{ECONOMETRIC RESULTS}

\subsection{Benchmark Estimations}

Table 2 reports the benchmark result of the estimation of equation [2]. All the models include sector, year, and prefecture dummies. We present here the results of a standard fixed-effect (FE) and the Arellano-Bond (AB) GMM estimator. In particular, columns [1] and [2] report the standard FE and the FE with a lagged dependent variable, respectively; columns [3] and [4] contain the one-step GMM and two-step GMM estimations, respectively. ${ }^{1}$ A comparison of the results based on the two estimation methods shows that the signs and significance levels of most of the variables are stable. In both the FE and the AB-GMM estimation, we add the one-year lag of the labor share to the explanatory variables (in columns [2-4]). The significantly positive coefficient is consistent with the expectations and confirms a remarkable feature of persistence of the levels of the labor share over time.

Firms with high total factor productivity have a smaller labor share, a result that is in line with the evidence that previous research has produced. ${ }^{2}$ On the other hand, the coefficients of tangible capital intensity, intangible assets' intensity, and ICT intensity are positive and significant, meaning that those factors of production are complementary to labor. As far as tangible capital is concerned, this result could be part of the explanation for the decline in the labor share in Japan, since the capital intensity has been declining in the country throughout the 2000s. ${ }^{3}$ The positive signs of intangible and ICT assets are probably due to the facts that the firms in the sample employ the large majority of labor on a permanent and full-time basis and that regular workers in Japan are normally associated with high formal or informal (experience) skills. It is therefore plausible that the result is connected to the dynamics of high-skilled labor that firms demand. If capital, intangible, and ICT assets are close complements to high-skilled workers, the expectation is that the labor share will increase with their accumulation.

A larger proportion of regular workers is associated with a larger labor share; this is likely to be due to regular workers' wage being higher than that of non-regular workers, on average.

1 Due to collinearity issues, the two-step GMM model does not include prefecture dummies.

2 We estimate the total factor productivity following the method that Olley and Pakes (1996) proposed and normalize it by subtracting the sector average of TFP in 2000. We also estimate the model using the non-normalized TFP and the normalized TFP based on the sector average of the TFP in 1995. The results are consistent with those presented in Table 2 and are available on request.

3 In the data that we use, the average capital-labor ratio gradually increased in the late 1990 s and reached its peak in 2002. After some years of relative stability, it declined steadily after 2008. 
Table 2: Drivers of the Labor Share at the Firm Level in Japan (2001-2012) - Internationalization Pattern of Firms Described by Means of the Set of Dummy Variables

\begin{tabular}{|c|c|c|c|c|}
\hline Estimation Method & $\begin{array}{l}\text { [1] } \\
\text { FE }\end{array}$ & $\begin{array}{l}\text { [2] } \\
\text { FE }\end{array}$ & $\begin{array}{c}{[3]} \\
A B \text { (onestep) }\end{array}$ & $\begin{array}{c}{[5]} \\
A B \text { (twostep) }\end{array}$ \\
\hline TFP (In) & $\begin{array}{c}-0.3552^{* * *} \\
{[-62.78]}\end{array}$ & $\begin{array}{c}-0.3344^{* * *} \\
{[-58.08]}\end{array}$ & $\begin{array}{c}-0.3697^{* * *} \\
{[-46.08]}\end{array}$ & $\begin{array}{c}-0.3630^{* * *} \\
{[-15.45]}\end{array}$ \\
\hline $\mathrm{KT}(\mathrm{In})$ & $\begin{array}{c}0.2016^{\star * *} \\
{[23.71]}\end{array}$ & $\begin{array}{c}0.1780^{\star \star \star} \\
{[20.86]}\end{array}$ & $\begin{array}{c}0.5356^{\star * \star} \\
{[41.29]}\end{array}$ & $\begin{array}{c}0.4931^{* * *} \\
{[18.69]}\end{array}$ \\
\hline E INT (In) & $\begin{array}{c}0.4763^{\star \star \star} \\
{[12.17]}\end{array}$ & $\begin{array}{c}0.4911^{* * *} \\
{[11.83]}\end{array}$ & $\begin{array}{c}0.5955^{* * *} \\
{[11.44]}\end{array}$ & $\begin{array}{c}0.5476^{* * *} \\
{[5.25]}\end{array}$ \\
\hline E ICT (In) & $\begin{array}{c}0.1299^{* \star *} \\
{[2.73]}\end{array}$ & $\begin{array}{c}0.1324^{* *} \\
{[2.26]}\end{array}$ & $\begin{array}{c}0.1498^{\star *} \\
{[2.25]}\end{array}$ & $\begin{array}{l}0.1213 \\
{[1.20]}\end{array}$ \\
\hline PAT (d) & $\begin{array}{l}0.002 \\
{[0.90]}\end{array}$ & $\begin{array}{c}-0.0015 \\
{[-0.69]}\end{array}$ & $\begin{array}{c}-0.0001 \\
{[-0.02]}\end{array}$ & $\begin{array}{c}-0.0019 \\
{[-0.60]}\end{array}$ \\
\hline REG (In) & $\begin{array}{c}0.0227^{* * *} \\
{[6.58]}\end{array}$ & $\begin{array}{c}0.0243^{* * *} \\
{[7.01]}\end{array}$ & $\begin{array}{c}0.0222^{* * *} \\
{[4.93]}\end{array}$ & $\begin{array}{c}0.0218^{* * *} \\
{[5.18]}\end{array}$ \\
\hline $\operatorname{EXP}(d)$ & $\begin{array}{c}0.0056^{* *} \\
{[2.25]}\end{array}$ & $\begin{array}{l}0.0021 \\
{[0.85]}\end{array}$ & $\begin{array}{c}-0.0012 \\
{[-0.36]}\end{array}$ & $\begin{array}{c}-0.0013 \\
{[-0.36]}\end{array}$ \\
\hline IMP (d) & $\begin{array}{c}0.0063^{\star \star *} \\
{[2.90]}\end{array}$ & $\begin{array}{c}0.0033 \\
{[1.51]}\end{array}$ & $\begin{array}{l}0.0037 \\
{[1.24]}\end{array}$ & $\begin{array}{l}0.003 \\
{[0.92]}\end{array}$ \\
\hline FDI (d) & $\begin{array}{c}-0.0028 \\
{[-0.94]}\end{array}$ & $\begin{array}{c}-0.0019 \\
{[-0.65]}\end{array}$ & $\begin{array}{c}-0.0011 \\
{[-0.27]}\end{array}$ & $\begin{array}{c}-0.0014 \\
{[-0.31]}\end{array}$ \\
\hline FOREIGN (d) & $\begin{array}{c}-0.0111^{* *} \\
{[-2.41]}\end{array}$ & $\begin{array}{c}-0.0057 \\
{[-1.27]}\end{array}$ & $\begin{array}{c}-0.0051 \\
{[-0.73]}\end{array}$ & $\begin{array}{c}-0.0026 \\
{[-0.40]}\end{array}$ \\
\hline SIZE (In) & $\begin{array}{c}0.0032 \\
{[0.99]}\end{array}$ & $\begin{array}{c}0.0163^{\star * *} \\
{[5.01]}\end{array}$ & $\begin{array}{c}-0.0115^{\star *} \\
{[-2.10]}\end{array}$ & $\begin{array}{l}-0.0107 \\
{[-1.32]}\end{array}$ \\
\hline SME (d) & $\begin{array}{c}-0.0095^{\star *} \\
{[-2.57]}\end{array}$ & $\begin{array}{c}-0.0077^{\star *} \\
{[-2.13]}\end{array}$ & $\begin{array}{c}-0.0048 \\
{[-0.93]}\end{array}$ & $\begin{array}{l}-0.004 \\
{[-0.63]}\end{array}$ \\
\hline PARENT (d) & $\begin{array}{c}-0.0080^{* *} \\
{[-2.42]}\end{array}$ & $\begin{array}{c}-0.0053 \\
{[-1.63]}\end{array}$ & $\begin{array}{c}-0.0013 \\
{[-0.25]}\end{array}$ & $\begin{array}{l}-0.001 \\
{[-0.18]}\end{array}$ \\
\hline FIRMAGE (In) & $\begin{array}{c}0.0154^{\star \star *} \\
{[5.56]}\end{array}$ & $\begin{array}{c}0.0156^{* * *} \\
{[5.30]}\end{array}$ & $\begin{array}{c}0.0197^{* * *} \\
{[4.14]}\end{array}$ & $\begin{array}{c}0.0244^{* * *} \\
{[3.04]}\end{array}$ \\
\hline LS(t-1) (In) & & $\begin{array}{c}0.2881^{* * *} \\
{[103.17]}\end{array}$ & $\begin{array}{c}0.3046^{\star * \star} \\
{[54.18]}\end{array}$ & $\begin{array}{c}0.2983^{\star * \star} \\
{[30.12]}\end{array}$ \\
\hline CONST & $\begin{array}{c}-0.7263^{\star \star *} \\
{[-8.02]}\end{array}$ & $\begin{array}{c}-0.5989^{* * *} \\
{[-6.49]}\end{array}$ & $\begin{array}{c}-0.5366^{\star * *} \\
{[-3.74]}\end{array}$ & $\begin{array}{c}-0.4781^{* * *} \\
{[-8.07]}\end{array}$ \\
\hline Sector dummies & Yes & Yes & Yes & Yes \\
\hline Prefecture dummies & Yes & Yes & Yes & No \\
\hline Time dummies & Yes & Yes & Yes & Yes \\
\hline R-squared & 0.0727 & 0.1669 & & \\
\hline$N$ & 145,994 & 126,756 & 112,060 & 112,060 \\
\hline
\end{tabular}

${ }^{*} p<0.1,{ }^{* *} p<0.05,{ }^{* * *} p<0.01$.

FE: Fixed-effect model, AB: 'Arellano-Bond' GMM estimation. 
Table 3: Labor Share at the Firm Level in Japan (2001-2012)_Internationalization Pattern of Firms According to the Continuous Variables

\begin{tabular}{|c|c|c|c|c|}
\hline & [5] & [6] & [7] & [8] \\
\hline Estimation Method & FE & FE & $A B$ & $A B$ \\
\hline \multirow[t]{2}{*}{ TFP $(\ln )$} & $-0.3559^{* * *}$ & $-0.3349^{* * *}$ & $-0.3698^{* * *}$ & $-0.3625^{\star * *}$ \\
\hline & {$[-62.88]$} & {$[-58.15]$} & {$[-46.10]$} & {$[-15.46]$} \\
\hline \multirow[t]{2}{*}{$\mathrm{K}_{\mathrm{T}}(\mathrm{In})$} & $0.2018^{* * *}$ & $0.1781^{* \star *}$ & $0.5348^{* \star *}$ & $0.4925^{* * *}$ \\
\hline & [23.73] & [20.87] & {$[41.23]$} & [18.69] \\
\hline \multirow[t]{2}{*}{ E INT (In) } & $0.4799^{* * *}$ & $0.4931^{\star \star \star}$ & $0.5972^{\star \star \star}$ & $0.5497^{* * *}$ \\
\hline & [12.27] & [11.88] & {$[11.47]$} & {$[5.26]$} \\
\hline \multirow[t]{2}{*}{ E ICT (In) } & $0.1314^{* * *}$ & $0.1330^{* *}$ & $0.1498^{\star *}$ & 0.1202 \\
\hline & {$[2.76]$} & {$[2.27]$} & {$[2.25]$} & [1.18] \\
\hline \multirow[t]{2}{*}{$\operatorname{PAT}(\mathrm{d})$} & 0.0025 & -0.0012 & 0.0001 & -0.0018 \\
\hline & {$[1.16]$} & {$[-0.56]$} & {$[0.04]$} & {$[-0.55]$} \\
\hline \multirow[t]{2}{*}{ REG (In) } & $0.0231^{* * *}$ & $0.0246^{\star \star \star}$ & $0.0225^{\star \star *}$ & $0.0222^{* * *}$ \\
\hline & [6.67] & [7.09] & [5.00] & {$[5.27]$} \\
\hline \multirow[t]{2}{*}{ EXP_s (In) } & $-0.0907^{* * *}$ & $-0.0816^{* * *}$ & $-0.0810^{\star * *}$ & $-0.0976^{* * *}$ \\
\hline & [-7.03] & {$[-6.27]$} & {$[-4.36]$} & {$[-3.84]$} \\
\hline \multirow[t]{2}{*}{ IMP_s (In) } & $0.0699^{* * *}$ & $0.0418^{\star \star \star}$ & -0.0092 & -0.0023 \\
\hline & [5.50] & {$[3.21]$} & {$[-0.47]$} & {$[-0.09]$} \\
\hline \multirow[t]{2}{*}{ FOREIGN_s (In) } & $-0.1524^{* * *}$ & $-0.1178^{\star *}$ & $-0.1725^{\star * *}$ & $-0.2109^{\star *}$ \\
\hline & {$[-3.24]$} & {$[-2.52]$} & {$[-2.80]$} & {$[-2.03]$} \\
\hline \multirow[t]{2}{*}{ SIZE (In) } & 0.0051 & $0.0178^{\star \star \star}$ & -0.0087 & -0.0078 \\
\hline & [1.57] & {$[5.46]$} & {$[-1.57]$} & {$[-0.97]$} \\
\hline \multirow{2}{*}{ SME (d) } & $-0.0097^{* * *}$ & $-0.0077^{* *}$ & -0.0046 & -0.004 \\
\hline & {$[-2.63]$} & {$[-2.13]$} & {$[-0.90]$} & {$[-0.64]$} \\
\hline \multirow[t]{2}{*}{ PARENT (d) } & $-0.0078^{* *}$ & -0.0052 & -0.0011 & -0.0011 \\
\hline & {$[-2.37]$} & {$[-1.59]$} & {$[-0.21]$} & {$[-0.18]$} \\
\hline \multirow[t]{2}{*}{ FIRMAGE (In) } & $0.0155^{\star * *}$ & $0.0155^{\star \star *}$ & $0.0198^{* * *}$ & $0.0247^{* * *}$ \\
\hline & [5.59] & {$[5.26]$} & [4.16] & [3.07] \\
\hline \multirow[t]{2}{*}{$\mathrm{LS}(\mathrm{t}-1)(\mathrm{In})$} & & $0.2878^{* * *}$ & $0.3052^{* * *}$ & $0.2984^{* * *}$ \\
\hline & & [103.08] & {$[54.28]$} & [30.15] \\
\hline \multirow[t]{2}{*}{ CONST } & $-0.7323^{* * *}$ & $-0.6048^{* * *}$ & $-0.5489^{* * *}$ & $-0.4907^{* * *}$ \\
\hline & [-8.09] & {$[-6.56]$} & {$[-3.83]$} & {$[-8.34]$} \\
\hline Sector dummies & Yes & Yes & Yes & Yes \\
\hline Prefecture dummies & Yes & Yes & Yes & No \\
\hline Time dummies & Yes & Yes & Yes & Yes \\
\hline R-squared & 0.0731 & 0.1673 & & \\
\hline $\mathrm{N}$ & 145,994 & 126,756 & 112,060 & 112,060 \\
\hline
\end{tabular}

${ }^{*} p<0.1,{ }^{* *} p<0.05,{ }^{* * *} p<0.01$.

FE: Fixed-effect model, AB: 'Arellano-Bond' GMM estimation. 
Surprisingly, and differing from previous research, no variable related to international activity has a significant coefficient. However, from this result only, we cannot conclude that overseas activities do not affect the labor share at all; the internationalization variables in Table 2 are dummy indicators. This means that we consider firms as companies operating abroad independent of the share of domestic/overseas activity.

In Table 3, we use continuous indicators instead of dummy variables as proxies for the internationalization patterns of firms. The results indicate that exports and foreign investment intensity decrease the labor share. Regarding the other explanatory/control variables, firm size does not provide clear indications concerning their impact on the labor share, and firm age has a positive coefficient, implying that the labor share tends to be larger for older firms. This is probably related to the fact that aged firms tend to have older workers, who earn higher wages due to their experience or their seniority (deferred compensation), under Japan's lifetime employment system.

\subsection{Estimation with Sector-Level Variables}

As we have already discussed in section 2, many preceding studies have found that the institutional features of both the final product market and the labor market affect the labor share. To check whether these relationships exist in Japan, we add a battery of industrylevel indicators to the set of explanatory variables (see Table A1 for their definition and Table A2 for some descriptive statistics). These sectoral measures, based on the information available in the JIP (Japan Industrial Productivity) database and meant to account for the institutional environment in which firms operate, are, with reference to the product market conditions: (i) the markup rate (log of sales/total cost of each sector); and (ii) an import penetration indicator, as a proxy for the level of competition due to imported goods. For the labor market, we include: (i) the share of high-skilled workers (in terms of working hours); (ii) the trade union density (the number of union members in the total number of employees); (iii) the share of female workers; and (iv) a measure of seniority of employment. All the indicators describe important characteristics of the product and labor markets in Japan (see Fukao and Perugini 2018). We run the estimates using the one-step GMM method with the inclusion of prefecture dummies and continuous variables regarding firms' international activity. Since sectorlevel variables are part of the set of independent variables, we do not include sector dummies in the model.

The results in Column [9] of Table 4 show that, consistent with previous works, the coefficient of the markup variable (in logs) is significant and negative, suggesting that stronger competitive pressure within a sector has the effect of increasing the labor share. In comparison with the results in Tables 2 and 3, the coefficient of TFP is considerably different, probably due to some omitted variable bias. The effect does not disappear if we saturate the model with other sector-level variables (see columns [2] to [6]). In column [10], we add the trade union organization rate as an explanatory variable, and its coefficient is negative and significant. However, the significance of the coefficient is not stable (see columns [12] to [14]), and this is may be due to the low levels and variability of the indicator. ${ }^{4}$

\footnotetext{
4 According to the information that the Ministry of Health, Labour and Wealth (December 2017) provided, the estimated trade union organization rate amounted to $17.1 \%$ in 2017 .
} 
Table 4: Labor Share at the Firm Level in Japan (2001-2012) and Institutional Variables (at the Sector Level)

\begin{tabular}{|c|c|c|c|c|c|c|}
\hline & [9] & [10] & [11] & [12] & [13] & [14] \\
\hline Estimation Method & $A B$ & $A B$ & $A B$ & $A B$ & $A B$ & $A B$ \\
\hline $\operatorname{TFP}(\operatorname{In})$ & $\begin{array}{c}-0.2705^{* * *} \\
{[-38.04]}\end{array}$ & $\begin{array}{c}-0.2724^{* * *} \\
{[-38.15]}\end{array}$ & $\begin{array}{c}-0.2717^{* * *} \\
{[-38.02]}\end{array}$ & $\begin{array}{c}-0.2748^{* * *} \\
{[-38.36]}\end{array}$ & $\begin{array}{c}-0.2885^{* * *} \\
{[-39.59]}\end{array}$ & $\begin{array}{c}-0.2963^{* * *} \\
{[-40.36]}\end{array}$ \\
\hline $\mathrm{KT}_{\mathrm{T}}(\mathrm{In})$ & $\begin{array}{c}0.5156^{* * *} \\
{[40.29]}\end{array}$ & $\begin{array}{c}0.5160^{* * *} \\
{[40.33]}\end{array}$ & $\begin{array}{c}0.5171^{\star * *} \\
{[40.37]}\end{array}$ & $\begin{array}{c}0.5239^{* * *} \\
{[40.80]}\end{array}$ & $\begin{array}{c}0.5225^{\star * \star} \\
{[40.69]}\end{array}$ & $\begin{array}{c}0.5262^{* * *} \\
{[40.97]}\end{array}$ \\
\hline E INT (In) & $\begin{array}{c}0.5681^{* * *} \\
{[10.86]}\end{array}$ & $\begin{array}{c}0.5680^{* * *} \\
{[10.86]}\end{array}$ & $\begin{array}{c}0.5683^{* * *} \\
{[10.86]}\end{array}$ & $\begin{array}{c}0.5731^{* * *} \\
{[10.96]}\end{array}$ & $\begin{array}{c}0.5682^{* * *} \\
{[10.86]}\end{array}$ & $\begin{array}{c}0.5747^{* * *} \\
{[10.99]}\end{array}$ \\
\hline E ICT (In) & $\begin{array}{c}0.1328^{\star *} \\
{[1.98]}\end{array}$ & $\begin{array}{c}0.1330^{* *} \\
{[1.99]}\end{array}$ & $\begin{array}{c}0.1334^{* *} \\
{[1.99]}\end{array}$ & $\begin{array}{c}0.1350^{* *} \\
{[2.02]}\end{array}$ & $\begin{array}{c}0.1368^{* *} \\
{[2.04]}\end{array}$ & $\begin{array}{c}0.1403^{* *} \\
{[2.10]}\end{array}$ \\
\hline PAT (d) & $\begin{array}{c}-0.0005 \\
{[-0.15]}\end{array}$ & $\begin{array}{c}-0.0005 \\
{[-0.16]}\end{array}$ & $\begin{array}{c}-0.0005 \\
{[-0.18]}\end{array}$ & $\begin{array}{c}-0.0003 \\
{[-0.11]}\end{array}$ & $\begin{array}{c}-0.0003 \\
{[-0.11]}\end{array}$ & $\begin{array}{c}-0.0004 \\
{[-0.14]}\end{array}$ \\
\hline REG (In) & $\begin{array}{c}0.0220^{\star \star *} \\
{[4.87]}\end{array}$ & $\begin{array}{c}0.0220^{* * *} \\
{[4.88]}\end{array}$ & $\begin{array}{c}0.0220^{* * *} \\
{[4.88]}\end{array}$ & $\begin{array}{c}0.0221^{* * *} \\
{[4.89]}\end{array}$ & $\begin{array}{c}0.0222^{\star * *} \\
{[4.91]}\end{array}$ & $\begin{array}{c}0.0220^{* * *} \\
{[4.87]}\end{array}$ \\
\hline EXP_s (In) & $\begin{array}{c}-0.0835^{\star * *} \\
{[-4.47]}\end{array}$ & $\begin{array}{c}-0.0833^{\star * *} \\
{[-4.46]}\end{array}$ & $\begin{array}{c}-0.0834^{* * *} \\
{[-4.46]}\end{array}$ & $\begin{array}{c}-0.0833^{* * *} \\
{[-4.46]}\end{array}$ & $\begin{array}{c}-0.0826^{\star * *} \\
{[-4.42]}\end{array}$ & $\begin{array}{c}-0.0836^{\star \star \star} \\
{[-4.47]}\end{array}$ \\
\hline IMP_s (In) & $\begin{array}{c}-0.0142 \\
{[-0.72]}\end{array}$ & $\begin{array}{c}-0.0144 \\
{[-0.73]}\end{array}$ & $\begin{array}{c}-0.0142 \\
{[-0.72]}\end{array}$ & $\begin{array}{c}-0.0135 \\
{[-0.69]}\end{array}$ & $\begin{array}{c}-0.0133 \\
{[-0.68]}\end{array}$ & $\begin{array}{c}-0.0131 \\
{[-0.66]}\end{array}$ \\
\hline FOREIGN_s (In) & $\begin{array}{c}-0.1564^{* *} \\
{[-2.52]}\end{array}$ & $\begin{array}{c}-0.1564^{* *} \\
{[-2.52]}\end{array}$ & $\begin{array}{c}-0.1548^{\star *} \\
{[-2.50]}\end{array}$ & $\begin{array}{c}-0.1534^{* *} \\
{[-2.47]}\end{array}$ & $\begin{array}{c}-0.1586^{* *} \\
{[-2.56]}\end{array}$ & $\begin{array}{c}-0.1617^{\star \star \star} \\
{[-2.61]}\end{array}$ \\
\hline SIZE (In) & $\begin{array}{c}0.0016 \\
{[0.29]}\end{array}$ & $\begin{array}{c}0.0013 \\
{[0.24]}\end{array}$ & $\begin{array}{c}0.0012 \\
{[0.22]}\end{array}$ & $\begin{array}{c}0.0009 \\
{[0.17]}\end{array}$ & $\begin{array}{c}0 \\
{[-0.00]}\end{array}$ & $\begin{array}{c}-0.0001 \\
{[-0.02]}\end{array}$ \\
\hline SME (d) & $\begin{array}{c}-0.0049 \\
{[-0.95]}\end{array}$ & $\begin{array}{l}-0.005 \\
{[-0.95]}\end{array}$ & $\begin{array}{c}-0.0049 \\
{[-0.94]}\end{array}$ & $\begin{array}{c}-0.0048 \\
{[-0.92]}\end{array}$ & $\begin{array}{c}-0.0049 \\
{[-0.94]}\end{array}$ & $\begin{array}{c}-0.0049 \\
{[-0.94]}\end{array}$ \\
\hline PARENT (d) & $\begin{array}{c}-0.0008 \\
{[-0.15]}\end{array}$ & $\begin{array}{c}-0.0007 \\
{[-0.14]}\end{array}$ & $\begin{array}{c}-0.0006 \\
{[-0.12]}\end{array}$ & $\begin{array}{c}-0.0008 \\
{[-0.16]}\end{array}$ & $\begin{array}{r}-0.0007 \\
{[-0.13]}\end{array}$ & $\begin{array}{c}-0.0004 \\
{[-0.07]}\end{array}$ \\
\hline FIRMAGE (In) & $\begin{array}{c}0.0177^{\star * *} \\
{[3.70]}\end{array}$ & $\begin{array}{c}0.0176^{* * *} \\
{[3.67]}\end{array}$ & $\begin{array}{c}0.0174^{* * *} \\
{[3.65]}\end{array}$ & $\begin{array}{c}0.0180^{* * *} \\
{[3.76]}\end{array}$ & $\begin{array}{c}0.0176^{* * *} \\
{[3.68]}\end{array}$ & $\begin{array}{c}0.0175^{\star * *} \\
{[3.66]}\end{array}$ \\
\hline MARK-UP & $\begin{array}{c}-0.1471^{* * *} \\
{[-9.94]}\end{array}$ & $\begin{array}{c}-0.1409^{* * *} \\
{[-9.43]}\end{array}$ & $\begin{array}{c}-0.1432^{* * *} \\
{[-9.56]}\end{array}$ & $\begin{array}{c}-0.1328^{* * *} \\
{[-8.83]}\end{array}$ & $\begin{array}{c}-0.1045^{\star * *} \\
{[-6.87]}\end{array}$ & $\begin{array}{c}-0.0819^{* \star *} \\
{[-5.32]}\end{array}$ \\
\hline UD & & $\begin{array}{c}-0.0100^{\star * *} \\
{[-2.98]}\end{array}$ & $\begin{array}{c}-0.0102^{\star * *} \\
{[-3.02]}\end{array}$ & $\begin{array}{c}-0.0036 \\
{[-1.02]}\end{array}$ & $\begin{array}{c}0.0035 \\
{[1.00]}\end{array}$ & $\begin{array}{c}-0.0046 \\
{[-1.25]}\end{array}$ \\
\hline HIGH SKILLED & & & $\begin{array}{c}0.9252^{* *} \\
{[2.10]}\end{array}$ & $\begin{array}{l}0.1201 \\
{[0.27]}\end{array}$ & $\begin{array}{c}1.0386^{* *} \\
{[2.29]}\end{array}$ & $\begin{array}{c}0.5441 \\
{[1.19]}\end{array}$ \\
\hline FEMALE & & & & $\begin{array}{c}0.0450^{* * *} \\
{[6.80]}\end{array}$ & $\begin{array}{c}0.0507^{* * *} \\
{[7.64]}\end{array}$ & $\begin{array}{c}0.0325^{* * *} \\
{[4.68]}\end{array}$ \\
\hline SENIORITY & & & & & $\begin{array}{c}0.1529^{* * *} \\
{[11.72]}\end{array}$ & $\begin{array}{c}0.1464^{* * *} \\
{[11.21]}\end{array}$ \\
\hline IMPORT_PENETR & & & & & & $\begin{array}{c}0.0217^{* * *} \\
{[8.90]}\end{array}$ \\
\hline $\mathrm{LS}(\mathrm{t}-1)(\ln )$ & $\begin{array}{c}0.3075^{\star * *} \\
{[54.42]}\end{array}$ & $\begin{array}{c}0.3074^{* * *} \\
{[54.39]}\end{array}$ & $\begin{array}{c}0.3079^{* * *} \\
{[54.52]}\end{array}$ & $\begin{array}{c}0.3082^{* * *} \\
{[54.58]}\end{array}$ & $\begin{array}{c}0.3100^{* * *} \\
{[54.86]}\end{array}$ & $\begin{array}{c}0.3102^{* * *} \\
{[54.91]}\end{array}$ \\
\hline CONST & $\begin{array}{c}-0.5528^{* * *} \\
{[-3.90]}\end{array}$ & $\begin{array}{c}-0.5179^{* * *} \\
{[-3.64]} \\
\end{array}$ & $\begin{array}{c}-0.8233^{* * *} \\
{[-4.05]}\end{array}$ & $\begin{array}{c}-0.5274^{* *} \\
{[-2.56]}\end{array}$ & $\begin{array}{c}-0.9414^{* * *} \\
{[-4.52]}\end{array}$ & $\begin{array}{c}-0.7107^{* * \star} \\
{[-3.39]}\end{array}$ \\
\hline Sector dummies & No & No & No & No & No & No \\
\hline Prefecture dummies & Yes & Yes & Yes & Yes & Yes & Yes \\
\hline Time dummies & Yes & Yes & Yes & Yes & Yes & Yes \\
\hline $\mathrm{N}$ & 112,060 & 112,060 & 112,060 & 112,060 & 112,060 & 112,060 \\
\hline
\end{tabular}

${ }^{*} p<0.1,{ }^{* *} p<0.05,{ }^{* * *} p<0.01$.

$\mathrm{AB}$ : 'Arellano-Bond' GMM estimation. 
The share of high-skilled workers also shows unstable significance in our estimation; the sign is always positive but is statistically significant only in columns [3] and [5]. One possible explanation for this result is that other explanatory variables, such as expenditures on intangibles and ICT, innovation, and internationalization activity, already account for the importance of high-skilled labor at the firm level.

In columns [13] and [14], we add the variable of seniority, which we measure as the ratio of the number of employees of different age groups (over 35 years old/under 35 years old). ${ }^{5}$ Contrary to our expectation, the impact of the share of female workers is positive and significant (columns [13] and [14]). However, in the first place, we should note that the result does not strictly reflect a positive correlation between the firm-level share of female workers and the labor share, as the indicator is at the sector level. Second, we have to bear in mind that the share and the number of female workers in the manufacturing industry decreased in Japan during the 2000s, along with a decrease in the numbers of firms and total workers. 6 Combined with the shift to high-skilled labor that many firms made, this could mean that female workers who entered manufacturing employment held higher levels of education and attained relatively high wage positions, therefore driving the positive correlation observable between female work and the labor share. ${ }^{7}$

The strongly positive coefficient of the import penetration ratio is also opposite to our expectation (column [14]). ${ }^{8}$ This is probably due to the fact that import penetration has two effects; one is to reduce employment and wages, and the other concerns firms' survival rate, sales, and value added. The result may imply that the latter effect prevailed in Japan during the 2000s. Another possible explanation is that import penetration reflects the outsourcing of unskilled-labor-intensive production processes, which increases the share of skilled workers and consequently the labor share. This would also explain why, when we add the import penetration and skilled worker variables simultaneously, the coefficient of the second variable becomes insignificant.

\section{CONCLUDING REMARKS}

In this paper, we presented an analysis of the determinants of the labor share in Japan in the 2000s based on firm-level data. This is, to our knowledge, the first micro-level study on the labor share for this country. Our outcomes can be summarized as follows. As in many previous studies, a stable correlation between the total factor productivity and the labor share emerges. Noteworthy and original evidence is the significant and positive impact of tangible capital intensity, intangible assets, and ICT expenditures on the labor share. Regarding the role of intangible assets, our findings are consistent with those of Perugini, Vecchi, and Venturini (2017), who showed that increasing

5 We also estimate the model with a different age threshold (40-year-olds and 45-year-olds). The results are very similar to the ones that we present in Table 4 and are available on request.

6 According to the "Labour Force Survey" that the Ministry of Internal Affairs and Telecommunication implemented, the number of female workers in the manufacturing industry was 4.33 million in 2002, following the application of the new industrial classification, but decreased to 3.17 million in 2012. During this period, except for 2006 , it consistently decreased. During the same period, the proportion of women in manufacturing workers also declined from $33.5 \%$ to $29.5 \%$.

7 According to our data, the correlation coefficient between the sector-level labor share and the female employment share amounted, for the whole period, to 0.0877. On a year-by-year basis, it increased steadily over time.

8 We also run estimates using an alternative definition of import impacts (import/output), and these largely confirm the results. Furthermore, dropping the firm-level dummy variable for imports does not make any significance difference to the outcomes that we present in Table 4. 
investments in intangible assets, such as goodwill, brand development, and training, drive the labor share upward. They based their analysis on firm data for six EU countries (Austria, France, Germany, Hungary, Italy, and Spain), and their interpretation was that investments in intangible assets require highly skilled workers who command higher wages and therefore increase the labor share. Our results indicate that a similar mechanism might hold in Japan, with expenditure for intangible assets, such as R\&D and advertisement, accompanying a higher demand for skilled workers and, through this channel, increasing the labor share.

As for internationalization activities, especially exporting, our paper is consistent with the results of previous research that has highlighted a negative impact on the labor share. However, in Japan, the effect tends to be irrelevant for firms with a small share of international activities and limited only to firms that are more active on international markets. This result might be related to the need for high-level skills and knowledge to operate abroad, which are probably internalized only by firms with international engagements exceeding a certain threshold.

Our analysis also reveals that, contrary to expectations, the proportion of female workers has a positive effect on the labor share. However, our panel data lack some important workers' information, such as education, career, and experience at the firm level. The fact that we approximate such information with variables at the sector level might be at the basis of this unexpected result. Further research is necessary on such crucial and socially sensitive aspects, by means of matched data that combine firms' and workers' information. This is one avenue in which the present research requires development.

Finally, we would like to point out the influence of institutional factors on our results, especially those related to the labor market. An important characteristic of Japan's labor market is the so-called lifetime employment and seniority system. Although the system has undergone a gradual review since the 1990s, in the 2000s, manufacturing firms characterized by this system still accounted for a large share of the total. Our analysis reflects this in the positive effects of the ratio of regular employees and seniority. A deeper analysis of the effect of country- or sector-specific institutional settings on the share of output accruing to labor at the firm level is another priority on our future research agenda. 


\section{REFERENCES}

Acemoglu, D., and D. Autor. 2011. "Skills, Tasks and Technologies: Implications for Employment and Earnings." In Handbook of Labour Economics, Vol. 4B, chapter 12, 1043-166. Elsevier, North-Holland.

Agnese, P., and H. Sala. 2011. "The Driving Forces Behind the Falling Labour Share and Persistent Unemployment in Japan." Pacific Economic Review 16 (5): 577-603.

Antràs, P. 2004. "Is the U.S. Aggregate Production Function Cobb-Douglas? New Estimates of the Elasticity of Substitution." Contributions in Macroeconomics 4 (1) [online]. doi:10.2202/1534-6005.1161.

Arellano, M., and S. Bond. 1991. "Some Tests of Specification for Panel Data: Monte Carlo Evidence and an Application to Employment Equations." Review of Economic Studies 58: 277-97.

Arpaia, A., E. Prez, and K. Pichelmann. 2009. Understanding Labour Income Share Dynamics in Europe. MPRA paper, 15649. University Library of Munich, Munich Personal RePEc Archive, Munich.

Autor, D., D. Dorn, L.F. Katz, C. Patterson, and J. Van Reenen. 2017. "Concentrating on the Fall of the Labour Share." American Economic Review: Papers \& Proceedings 107 (5): 180-5.

Azmat, G., A. Manning, and J. Van Reenen. 2012. "Privatization and the Decline of Labour's Share: International Evidence from Network Industries." Economica 79 (315): 470-92.

Baltagi Badi, H. 2001. Econometric Analysis of Panel Data (2nd edition). Wiley: Chichester.

Barkai, S. 2016. "Declining Labour and Capital Shares." Mimeo, University of Chicago.

Bassanini, A., and T. Manfredi. 2012. Capital's Grabbing Hand? A Cross-Country/ Cross-Industry Analysis of the Decline of the Labour Share. OECD Social, Employment and Migration Working Papers, 133, OECD, Paris.

Bental, B., and D. Demougin. 2010. "Declining Labour Shares and Bargaining Power: An Institutional Explanation." Journal of Macroeconomics 32: 443-56.

Bentolila, S., and G. Saint-Paul. 2003. "Explaining Movements in the Labour Share." Contributions to Macroeconomics 3 (1): 1-31.

Berkowitz, D., H. Ma, and S. Nishioka. 2015. Declining Labour Shares and Heterogeneous Firms. Working Paper 552. Stanford Centre for International Development, Stanford, US.

2017. Does Capital-Labour Substitution or Do Institutions Explain Declining Labour Shares? Working Paper 6060. Department of Economics, University of Pittsburgh, Pittsburgh.

Bernard, A.B., J.B. Jensen, S.J. Redding, and P.K. Scott. 2007. "Firms in International Trade." Journal of Economic Perspectives 21: 105-30.

Blanchard, O., and F. Giavazzi. 2003. "Macroeconomic Effects of Regulation and Deregulation in Goods and Labour Markets." Quarterly Journal of Economics 118 (3): 879-907. 
Bockerman, P., and M. Maliranta. 2012. "Globalization, Creative Destruction, and Labour Share Change: Evidence on the Determinants and Mechanisms from Longitudinal Plant Level Data." Oxford Economic Papers 64 (2): 259-80.

Caroli, E., and J. Van Reenen. 2001. "Skill-Biased Organizational Change? Evidence from a Panel of British and French Establishments." Quarterly Journal of Economics 116 (4): 1449-92.

Crinò, R. 2012. "Service Offshoring and the Skill Composition of Labour Demand." Oxford Bulletin of Economics and Statistics 74 (1): 375-401.

Dall'Aglio, V., M. Magnani, and P.L. Marchini. 2015. "A Firm Level Analysis of the Labour Share." Rivista Internazionale di Scienze Sociali 2: 179-210.

Davis, D. 1998. "Does European Unemployment Prop Up American Wages? National Labour Markets and Global Trade." American Economic Review 88: 478-94.

Decreuse, B., and P. Maarek. 2011. "Can the HOS Model Explain Changes in Labour Shares? A Tale of Trade and Wage Rigidities." Mimeo, HAL.

Elsby, M.W.L., B. Hobijn, and A. Sahin. 2013. "The Decline of the U.S. Labour Share." Brookings Papers on Economic Activity 47 (2): 1-63.

European Commission. 2007. The Labour Income Share in the European Union. In Employment in Europe 2007, 237-72. Luxembourg: Office for Official Publications of the European Communities.

Feenstra, R.C., and G.H. Hanson. 1999. "The Impact of Outsourcing and High Technology Capital on Wages: Estimates for the United States, 1979-1990." Quarterly Journal of Economics 114 (3): 907-40.

Fukao, K., and C. Perugini. 2018. The Long-Run Dynamics of the Labour Share in Japan. Discussion Paper Series A, 672. IER, Hitotsubashi University, Tokyo.

Growiec, J. 2012. "Determinants of the Labour Share: Evidence from a Panel of Firms." Eastern European Economics 50 (5): 23-65.

Guerriero, M., and K. Sen. 2012. What Determines the Share of Labour in National Income? A Cross-Country Analysis. IZA Discussion Papers 6643. Institute for the Study of Labour (IZA), Bonn.

Guscina, A. 2006. Effects of Globalization on Labour's Share in National Income. IMF Working Paper, 06294. Washington, DC: International Monetary Fund.

Harrison, A. 2002. "Has Globalization Eroded Labour's Share? Some Cross-Country Evidence." Mimeo, UC Berkeley.

Hutchinson, J., and D. Persyn. 2012. "Globalisation, Concentration and Footloose Firms: In Search of the Main Cause of the Declining Labour Share." Review of World Economics 148 (1): 17-43.

Hwang, D.S., and B.H. Lee. 2015. "Wage Share and Corporate Policies in Personnel Management in Korea: A Firm-Level Study." Mimeo, ILO.

ILO. 2011. "The Labour Share of Income: Determinants and Potential Contribution to Exiting the Financial Crisis." Chapter 3 in World of Work Report 2011: Making Markets Work for Jobs. Geneva: ILO.

IMF. 2007. "The Globalization of Labour." In World Economic Outlook April, 161-92. Washington, DC: IMF. 
Jaumotte, F., and I. Tytell. 2007. How Has the Globalization of Labour Affected the Labour Income Share in Advanced Countries? IMF Working Papers, 298, Washington.

Jayadev, A., 2007. "Capital Account Openness and the Labour Share of Income." Cambridge Journal of Economics 31 (3): 423-43.

Kaldor, N. 1961. "Capital Accumulation and Economic Growth." In The Theory of Capital, edited by F. Lutz. London: Macmillan.

Karabarbounis, L., and B. Neiman. 2014. "The Global Decline of the Labour Share." Quarterly Journal of Economics 129 (1): 61-103.

Koh, D., R. Santaeulàlia-Llopis, and Y. Zheng. 2016. Labour Share Decline and Intellectual Property Products Capital. Working Paper 927. Barcelona Graduate School of Economics, Barcelona.

Kyyra, T., and M. Maliranta. 2008. "The Micro-level Dynamics of Declining Labour Share: Lessons from the Finnish Great Leap." Industrial and Corporate Change 17 (6): 1147-72.

Lawless, M., and K.T. Whelan. 2011. "Understanding the Dynamics of Labour Shares and Inflation." Journal of Macroeconomics 33: 121-36.

Lileeva, A. 2008. "Trade Liberalization and Productivity Dynamics: Evidence from Canada." Canadian Journal of Economics 41: 360-90.

Melitz, M.J. 2003. "The Impact of Trade on Intra-Industry Reallocations and Aggregate Industry Productivity." Econometrica 71: 1695-725.

Ministry of Health, Labour and Wealth, Japan. 2017. Basic Survey of Labor Unions.

Olley, G. S., and A. Pakes.1996. "The Dynamics of Productivity in the Telecommunications Equipment Industry." Econometrica, 64 (6): 1263-1297.

O'Mahony, M., M. Vecchi, and F. Venturini. 2018. "The Long-Run Decline in Labour Share: Technology versus Institutions." In this volume.

OECD. 2011. Divided We Stand: Why Inequality Keeps Rising. Paris: OECD Publishing.

Perugini, C., M. Vecchi, and F. Venturini. 2017. "Globalisation and the Decline of the Labour Share: A Microeconomic Perspective." Economic Systems 41: 524-36.

Piketty, T. 2014. Capital in the Twenty-First Century. Cambridge, MA: Harvard University Press.

Piketty, T., and G. Zucman. 2014. "Capital is Back: Wealth-Income Ratios in Rich Countries 1700-2010." Quarterly Journal of Economics 129: 1255-310.

Piva, M., E. Santarelli, and M. Vivarelli. 2005. "The Skill Bias Effect of Technological and Organisational Change: Evidence and Policy Implications." Research Policy, Elsevier 34 (2): 141-57.

Rodrik, D. 1997. Has Globalization Gone Too Far? Washington, DC: Institute for International Economics.

Siegenthaler, M., and T. Stucki. 2015. "Dividing the Pie: The Determinants of Labour's Share of Income on the Firm Level." International Labour Relations Review 68 (5): 1157-94.

Slaughter, M.J. 2000. "Production Transfer within Multinational Enterprises and American Wages." Journal of International Economics 50: 449-90. 
Takeuchi, F. 2005. Causes of Decline in Labour's Share in Japan. JCER Researcher Report No. 53, The Japan Center for Economic Research, Tokyo.

Wakita, S. 2006. "The Lost Decade in the Japanese Labour Market: Labour's Share and Okun's Law." Public Policy Review 2 (1): 77-96.

Wood, A. 1994. North-South Trade, Employment and Inequality: Changing Fortunes in a Skill-Driven World. Oxford: Clarendon Press, Oxford. 


\section{APPENDIX}

Table A1: List of Variables, Acronyms, and Definitions

\begin{tabular}{|c|c|c|c|}
\hline Label & Level & Type & Description \\
\hline LS & Plant & Percentage & Cost of employees/value added \\
\hline TFP & Plant & Continuous & $\begin{array}{l}\text { Total Factor Productivity, estimated by Olley-Pakes } \\
\text { Method, normalised by sector average in } 2000\end{array}$ \\
\hline $\mathrm{K} \tau$ & Plant & Continuous & Real tangible fixed asset/real sales \\
\hline E INT & Plant & Continuous & $\begin{array}{l}\text { Real intangible expenditure (=R\&D expenditure + real } \\
\text { advertisement expenditure) / real sales }\end{array}$ \\
\hline E ICT & Plant & Percentage & Real cost of ICT/real sales cost \\
\hline PAT (d) & Plant & Binary & $\begin{array}{l}\text { Company having patents developed by itself } \\
(=1,0 \text { otherwise })\end{array}$ \\
\hline REG & Plant & Percentage & Regular employees/total employees \\
\hline $\operatorname{EXP}(d)$ & Plant & Binary & Company exporting outputs abroad $(=1,0$ otherwise) \\
\hline $\operatorname{IMP}(d)$ & Plant & Binary & $\begin{array}{l}\text { Company importing inputs from foreign countries } \\
(=1,0 \text { otherwise })\end{array}$ \\
\hline FDI (d) & Plant & Binary & Company having foreign subsidies $(=1$, otherwise 0$)$ \\
\hline FOREIGN (d) & Plant & Binary & $\begin{array}{l}\text { Company partially or completely by foreign company } \\
(=1 \text {, otherwise } 0)\end{array}$ \\
\hline EXP_s & Plant & Continuous & Export/Sales \\
\hline IMP_S & Plant & Continuous & Import/Sales Cost \\
\hline FOREIGN_S & Plant & Continuous & $\begin{array}{l}\text { Employees in foreign subsidies/total domestic } \\
\text { employees }\end{array}$ \\
\hline SIZE & Plant & Binary & Number of total domestic employees \\
\hline SME (d) & Plant & Binary & Firm with 300 or fewer employees \\
\hline PARENT (d) & Plant & Binary & Firm owned by other companies \\
\hline FIRMAGE & Plant & Continuous & Years from the establishment of the firm \\
\hline MARK-UP & Sector & Continuous & Sales/total cost \\
\hline UD & Sector & Percentage & Union members/total workers \\
\hline HIGH SKILLED & Sector & Percentage & $\begin{array}{l}\text { Number of hours worked by high skilled } \\
\text { workers/number of hours worked by total workers }\end{array}$ \\
\hline FEMALE & Sector & Percentage & Number of female workers/total workers \\
\hline SENIORITY & Sector & Continuous & $\begin{array}{l}\text { Number of employed }>35 \text { years old / number of } \\
\text { employed }<35 \text { years old }\end{array}$ \\
\hline IMPORT_PENETR & Sector & Continuous & Import/(Output + Import - Export) \\
\hline
\end{tabular}

Table A2: Summary Statistics of Sector Variables

\begin{tabular}{lcrrrr}
\hline \multicolumn{1}{c}{ Variables } & Observations & \multicolumn{1}{c}{ Mean } & \multicolumn{1}{c}{ Std } & Min. & \multicolumn{1}{c}{ Max. } \\
\hline MARK-UP & 147,725 & 0.990 & 0.095 & 0.751 & 1.331 \\
UD & 147,725 & 30.166 & 19.838 & 7.400 & 94.700 \\
HIGH SKILLED & 147,725 & 0.330 & 0.003 & 0.318 & 0.336 \\
FEMALE & 147,725 & 0.314 & 0.140 & 0.111 & 0.661 \\
SENIORITY & 147,725 & 2.434 & 0.592 & 1.391 & 5.686 \\
IMPORT_PENETR & 147,725 & 0.144 & 0.125 & 0.004 & 0.723 \\
\hline
\end{tabular}

